\title{
The Ethical Backlash of Corporate Branding
}

Guido Palazzo
Kunal Basu

\begin{abstract}
Past decades have witnessed the growing success of branding as a corporate activity as well as a rise in anti-brand activism. While appearing to be contradictory, both trends have emerged from common sources - the transition from industrial to post-industrial society, and the advent of globalization - the examination of which might lead to a socially grounded understanding of why brand success in the future is likely to demand more than superior product performance, placing increasing demand on corporations with regard to a broader envelop of socially responsible behavior. Directions for strategic and managerial options are suggested.
\end{abstract}

KEY WORDS: corporate branding, consumption, CSR, globalization, identity, NGO activism, values

The Fortune list of "the World's Most Admired Companies" is led by Wal-Mart (Hjelt, 2004). The company is praised for its outstanding distribution system, low prices and productivity, and most significantly, its brand power (Useem, 2004). Paradoxically, the same company is often viewed as a preferred target by the No Logo movement (Klein, 2000), accused of aggressive expansion at the expense of local retailers, sweatshop involvement in sourcing its products, alongside low wages and poor working

Guido Palazzo is Assistant Professor for Business Ethics at the University of Lausanne. He graduated in Business Administration at the University of Bamberg and earned his Ph.D. in Political Philosophy from the University of Marburg. His research interests are in Corporate Social Responsibility, Corporate Branding, Democratic Theory, and Organizational Ethics.

Kunal Basu is a University Reader in Marketing at Said Business School, University of Oxford. He earned his Ph.D. in Marketing from the University of Florida. His research interests are in Corporate Social Responsibility Strategy and Brand Management. conditions for its employees. The Wal-Mart brand melds two societal narrations: brand power, particularly, the emergence and the remarkable success of corporate branding strategies; and the rise of anticorporate rhetoric and activism. A similar scenario surrounds other successful corporate brands such as Nike, Microsoft, or McDonald's, one that involves two different sets of actors: brand believers and antibrand activists.

The rise of branding as a powerful tool to attract and retain customers has seen wide-ranging discussion in the academic literature in marketing (see Aaker, 1996; de Chernatony and McDonald, 1992) and has been substantially commented upon in the popular press. Likewise, the genesis and growth of the No Logo movement has enjoyed both commentary (e.g., Bethune 2000; Cramp 2001; Economist 2001; Siegel 2000) and criticism in the managerial literature (Chevalier and Mazzalovo, 2004). However, as stated by Crossley (2002), the conjunction of the two has received scant scholarly consideration, particularly in analyzing their societal and organizational roots, with a view toward developing guidelines for conflict resolution.

Our article will take the form of a conceptual essay in addressing the above with a central proposition that argues for seeking an understanding of the brand and anti-brand phenomena in terms of more fundamental societal trends, particularly that of a rising individualization and globalization. Both are seen as impacting on notions of identity, consumption and values within segments of citizenry in postindustrial western societies, with potentially far-reaching impact on how corporations and their brands are perceived. A multi-disciplinary view will be applied with reliance on the marketing literature in discussing key trends in the domain of branding, 
on political theory in addressing societal activism, and finally, the delineation of the relationship between the two will take us into prevalent perspectives on corporate social responsibility (CSR). The article is organized as follows: the next section will present a framework of Scapes, to capture the complex interdependencies among our key constructs (identity, consumption, and values), followed by discussions on the links between these, i.e., identity-based consumption, value-driven activism, and the role of CSR in encouraging coherence between consumption and life values that are related to an individual's identity. Reflections on possible managerial interventions will be offered in conclusion.

\section{A framework of Scapes}

Appadurai (1990) has suggested that the new global cultural environment be viewed as a 'complex, overlapping, disjunctive order', which can no longer be understood in terms of distinct conceptual entities such as centre/periphery, surplus/deficit, or consumers/producers. Instead, he suggests investigating 'landscapes' that could serve as building blocks linking individual perceptions to social formations, such as ethnoscapes, technoscapes, mediascape, financescape, and ideoscape, the suffix 'scape' indicating both fluidity and multidimensionality. Our analysis of societal trends to explain the twin phenomena of brand success and anti-brand activism will similarly rely on three such landscapes: Identityscape, Consumption-scape, and Value-scape, a-priory consideration of which suggests them to be intimately linked. While values are central to the development of identity (Hitlin, 2003; Taylor, 1989), both are rendered vulnerable by societal change (Beck-Gernsheim and Beck, 2002; Giddens, 1991), leading to attempts at identity-reconstruction within which consumption decisions are likely to play a significant role (Arnould and Price, 2000; Belk, 1988; Gabriel and Lang, 1995). Thus, the inner dynamics of our three scapes and their interrelationships might help to throw light on how brands are perceived, why social activism might take the form of brand opposition among some members of society, and the potential role of CSR in bridging the conflicting trends (Figure 1).

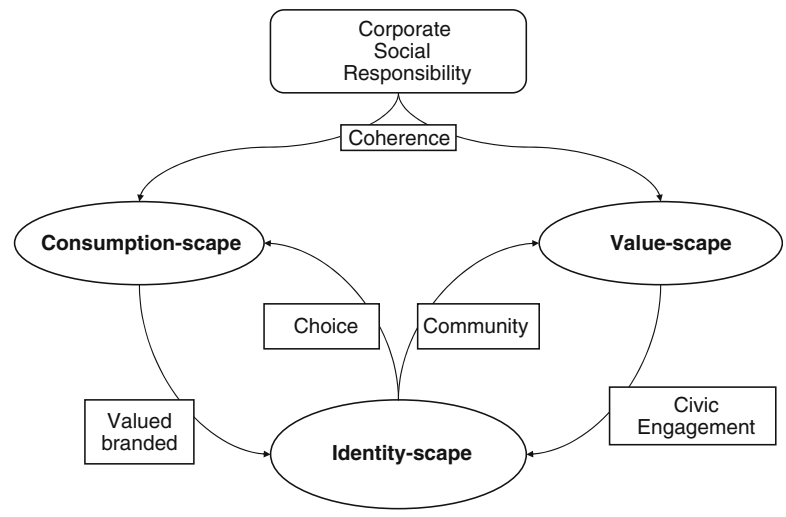

Figure 1. A Framework of Scapes.

Identity-scape

While industrial societies of the 20th century were characterized by relative cultural homogeneity, post-industrial western societies are seen as moving toward fragmented and pluralistic cultures (Giddens, 1991; Beck et al., 1995). With traditional sources of identity (e.g., kinship) offering a stable set of expectations and clearly defined roles losing their authority, critical reflections have come to substitute traditional prescriptions in charting an individual's behaviors. Societal transition, thus, has created a shift from traditional anchors based on 'belonging' to new anchors of identity definition based on choice (Giddens, 1991). Blind rules are increasingly being replaced by a reflexive process of identity formation (Beck-Gernsheim and Beck, 2002), with 'intrusion of reflection into life histories and cultural traditions' (Habermas, 1996, p. 97). It has been claimed that the transition to a post-industrial society is characterized by instabilities, contingencies, dissensions and paradoxes, creating pressure and ultimately damaging the coherence that creates order in an individual's life. Post-modern theory has interpreted this as a liberation from external authorities: stable identity is replaced by an individual process of deconstruction and reconstruction in an extremely adaptive process of shaping the self (Gabriel and Lang 1995, p. 40), with consumption seen as a key part of the postmodern actor's self-constructing activities. For postmodern thinkers, the fragmentation and fluidity of the self symbolizes the emancipation of the individual with "the theaters of consumption" serving 
as key driving forces (Firat and Dholakia, 1998). However, in his research on cognitive dissonance, Festinger (1957) has found evidence that individuals continue to preserve their behavioural patterns even under contextual transformation. In contrast to post-modern philosophy, a cognitive dissonance view suggests a human need not to give up authenticity but 'to keep the narrative going' (Giddens, 1991, p. 54; also Sennett, 1998), resulting in a 'fight' for rebuilding a self-consciousness, selfrealization, and self-determination (Beck et al., 1995, 2003; Erikson, 1968; Habermas, 1998a). While we agree with the post-modern view of consumption driven reshaping of individual and communal identities, it would be unrealistic to reject completely individuals' needs for coherence and stability. Indeed large parts of observable consumer behavior illustrate just such a need to maintain stability in certain aspects of identity across time and behaviours.

\section{Consumption-scape}

While the notion that consumption might impact on identity formation is not new, for decades it has been interpreted largely as a negative influence - as a form of manipulation and as a shallow substitute for "real" identity (e.g., Fromm, 1976; Marcuse, 1964; also see similar arguments in recent literature: e.g., Klein, 2000; Lasn, 1999). Such a negative interpretation of the identity-consumption link might indeed appear valid in some consumption domains (see, for example, the discussion on tobacco marketing, Palazzo and Richter, 2005). Alternative interpretations, however, draw on a more positive view of the presumed linkage such as the cognitive and moral autonomy of the consuming individual (Belk et al., 1989; Fournier, 1998). As described by Gabriel and Lang (1995), consumption has emerged as an activity of growing importance in the lives of citizens of post-industrial western societies, and constitutes a key element in the process of identity formation. While a large volume of literature has focused on the role of consumption in identity formation (in consumer research: Belk, 1988; Elliot, 1997; Gabriel and Lang, 1995; McCracken, 1986; Reed, 2004; Shankar and Fitchett, 2000; sociology: see Corrigan, 1997; and anthropology: see Douglas,
1975) largely focusing on the American experience, with the shopping mall replacing the factory as a defining space (Ritzer, 1999) and the average American consuming twice as much as 40 years ago (Schor, 1991), it has nevertheless drawn attention to the core thesis that consumption decisions and the result of consumption have become significant contributors to redefining identity at a time of accelerated social change that emphasizes a rising individualization. Of particular relevance to our discussions is the proffered role of consumption in creating meaning (Belk, 1988; Elliot and Wattanasuwan, 1998; Schau, 2000) in preserving and strengthening a threatened identity (O'Donohoe, 1999; Schouten, 1991).

\section{Value-scape}

The role of values as providing anchor to the development and preservation of identity has been discussed by several authors (see Taylor, 1989), particularly that of providing an 'internal moral compass' that helps to structure and interpret external phenomena and relate such to one's own self-concept (Hitlin and Piliavin, 2004, p. 362). As described by Kamakura and Novak (1992), values are deeply rooted in the cognitive system of an individual, building the foundation for identity-driven activities (Shamir et al., 1993). Crucial to the manifestation of authenticity and self-worth, it is claimed by Gecas (2000, p. 95) that 'people feel pride and satisfaction at the affirmation of their values, guilt and shame if not living up to their values, and anger or fear when their values are threatened.'

In the domain of consumption, researchers have shown that increasingly consumers tend not to buy product attributes per se, but a product's capacity to mirror their values and lifestyle needs (Clark and Fijimoto, 1990; Czellar and Palazzo, 2004). Thus, value-based marketing strategies have been claimed to strengthen customer loyalty (Urde, 2003). Some authors have argued that such a strategy appears to be more effective for companies that display a "distinct social mission," such as Patagonia, Ben and Jerry's and the Body Shop (Kay, 2006, p. 754). Values, in any case, are found to be 'more closely related to behavior than personality traits' that have in the past been viewed as accurate predictors of consumer 
choice (Kamakura and Novak, 1992, pp. 119-120), being more central and more immediately related to purchase motivations than even attitudes. Accordingly, Durgee et al. (1996, p. 90) have argued that 'one of the most powerful ways to understand and touch consumers is to understand their values and value systems.'

As our previous discussion of the three scapes shows, the process of identity-reconstruction in a context of societal change is likely to draw on valuedriven consumption as an important ingredient to restore coherence. Such a process then would be sensitive to the nature of the change (i.e., individualization and globalization) as well as the changing dynamics of branding as perceived by consumers, with exchanges among the scapes, in turn, shedding light on the twin phenomena of brand success and anti-brand activism. Specifically, the following propositions underscore the key exchanges within our framework of scapes:

- A gradual shift in branding strategy - from showcasing product features (product brand) to communicating corporate values (corporate brand) is likely to support consumers' growing identity needs defined by deliberate choices, given the emphasis on and salience of values rather than merely consumption benefits.

- Reconstruction of identity is likely to encompass values that transcend simply consumption related aspects of life, embracing broader dimensions (e.g., ecology, social justice) which, in turn, could shape the nature of civic engagement, with globalization bringing to focus the role of large corporations as they relate to such 'life-values.'

- Growing links between identity, consumption and values, brought on by societal change is likely to lead consumers to view corporations as 'wholes', as repositories and suppliers of a diverse range of values, with growing scrutiny with regard to the internal consistency among these. Thus, consumption values are likely to be balanced against life values with growing demand to embed superior brand performance within overall ethical business practice.
In the following sections, each of the above propositions will be developed, the first to underscore societal as well as organizational bases for growing brand success; the second to investigate possible roots of anti-brand activism; and the third to investigate the 'balancing role' of CSR in resolving conflicting perceptions regarding brands.

\section{Identity-consumption: rise of the corporate brand}

The key role of branding within marketing is seen as one of differentiating the firm's offer as assessed by target consumers with respect to competing offers. As articulated by Simoes and Dibb (2001), consumers buy brands in the expectation of fulfilling a need through consumption of a bundle of attributes, the choice of which depends upon the subjective judgment of quality (Berry, 2000; Cleary, 1981; Keller, 2003; O’Malley, 1991; Schmitt and Simonson, 1997). As a manifestation and summary of product attributes, a product brand helps to locate the whole offer within the consumers' perceptual space, thus aiding a quick and efficient choice. A whole genre of methodologies, ranging from multidimensional scaling to conjoint analysis, is aimed at providing managers with suitable metrics to determine the appropriate location of their brands in the mind-frames of their target consumers.

Despite the wide application and continued use of product branding, the role of corporate branding has emerged in recent times as a way to achieve the desired differentiation relying on a different set of qualities to the more traditional use of product attributes. The emphasis of corporate branding lies in the articulation of a set of values that span the corporation as a whole, casting an umbrella over all its offerings across diverse marketplaces. Corporate values, such as technological superiority (e.g., Honda), market leadership (e.g., Citi Group), social responsibility (e.g., Shell), or people excellence (e.g., Disney) replace product features in corporate branding. At times an aggregation of product features across the corporation's range of offers leads to the fixing of corporate brand values. At other times, a dominant product brand (e.g., Coke) may prompt the emergence of the corporate brand, which incorporates the products brand's qualities in 
addition to a broader set of values (e.g., the Coca-Cola corporate brand standing for excitement and energy, emerging strongly from the Coke product, i.e., cola brand).

While corporate brands are still far from replacing product brands in their entirety (about $75 \%$ of the top 100 brands though show strong corporate value articulation, even if the genesis of the brand name might reside within a specific product brand; Business Week, 2005), the growing popularity of corporate branding may be attributed to: I. Growing product parity (i.e., lack of feature-based differentiation) among competing brands (Cova, 1997; Gabriel and Lang, 1995; Holt, 1997); II. Information overload (in visual and verbal advertising) with regard to product specifications, reducing the effectiveness of feature-based differentiation (Aaker and Joachimsthaler, 2000, p. 7). As claimed by several authors (Aaker, 2004; Hatch and Schultz, 2003, p. 1046), corporate brands offer a trust-creating alternative in channeling consumer awareness in the backdrop of overwhelming brand multiplication, attracting their relevant audiences like 'a beacon in a fog'; and III. Opportunity for extending business reach through successful brand leverage that focuses on organizational values/capabilities rather than those tied to the requirements of a specific product market.

The design of a corporate brand is based on a coherent system of interrelated ideas that express corporate characteristics and thereby cause higher recall than a product brand (Beardsworth and Bryman, 1999; Pine and Gilmore, 1999; Ritzer, 1999; Schmitt and Simonson, 1997). The branding narrative aims at generating a good reputation and delivering a consistent brand experience. It becomes a statement of what can be expected from a corporation by all its stakeholders (Hatch and Schultz, 2003; Schultz and de Chernatony, 2002; Urde, 2003). Therefore, the branded values must be evident throughout all dimensions of corporate behavior (Aaker, 2004; Hatch and Schultz, 2001; Urde, 2003), aligning the whole organization around the brand narrative (de Chernatony, 1999; Schmitt and Simonson, 1997; Thompson et al., 2006; Tilley, 1999, Urde, 1999; Simoes and Dibb, 2001). A corporate brand is linked to the promise that a company's behavior can be measured against the branded values (Berry, 2000); the brand, thus, becoming the prod- uct, with values serving as reference points rooting it within the consumers' self-identities.

Further, value-based corporate branding provides strong support to consumers' identity projects, serving 'to structure our experiences' (Hitlin and Piliavin, 2004 , p. 363) at a time of societal transformation. It successfully addresses the growing desire for orientation, and if a brand is indeed able to mirror the values of the consumer it becomes a means to shape and express identity as consumers attempt to distinguish between brands that are credible, value-laden and authentic from those that are not (Lafferty and Goldsmith, 1998). As described by Bhattacharya and Sen (2003), the perceived fit between a company's character and a customer's character can become a source for self-definition. 'Consumers are likely to find a company's identity more attractive when it matches their own sense of who they are ... (i.e. their traits and values)' (Bhattacharya and Sen, 2003, p. 80). A generator of values and meaning, a sophisticated brand narrative helps to reconstruct identities damaged by societal change.

An ideal corporate brand creates a powerful corporate myth that is deeply anchored in the consumers' life-world, capable of turning ordinary consumption into a quasi-religious activity. In such a case, consumers, for instance, behave as loyal Coca-Cola believers or as members of the Apple community (Belk et al., 1989). Even the rejection of certain brands (e.g., diet version of a given cola brand, Microsoft products) can have a fundamentalist persistence (Fournier, 1998), value-based branded consumption becoming a 'vehicle of transcendent experience' (Belk et al., 1989, p. 2). Schouten and McAlexander's discussion of Harley-Davidson, which they describe as 'a religious icon, around which an entire ideology of consumption is articulated' (1995, p. 50) could provide a glimpse of the mythical power of a corporate brand in delivering an identitycreating narrative among its loyal consumers.

While product brands continue to be successful in domains of relatively standardized mass consumption, corporate brands have emerged to support the growing need for orientation in fragmented and pluralized societies. Here the corporate branding story delivers a set of abstract values in a concrete narrative context that can be deeply rooted in consumers' lives, thus competing with weakened traditional sources of identity and successfully 
addressing the growing desire for normative orientation.

\section{Identity-value: new locus of civic engagement}

As described above, while corporate branding has profited as a result of the growing need for orientation and identity-reconstruction among consumers, such identity needs have not been limited to the consumption domain alone, playing an increasingly important role in civic activism as well. We argue that understanding the growing trend toward civil society engagement is likely to shed light on the twin phenomena of corporate brand success and antibrand activism. It is our view that the very same desire for normative orientation which leads to the success of value-based branding (discussed below within the identity-consumption link) could provoke a public backlash against brands (discussed below within the identity-value link).

Several authors (Castells, 1996; Touraine, 1994) have claimed that identity has become the main driver of civic activism, replacing the idea of utilitydriven class struggle. Whereas the industrial society of the last century was characterized by conflicts over distribution, conflicts in post-industrial western societies have more to do with 'the grammar of forms of life' (Habermas, 1987, p. 392). Such identity-based movements strive for recognition with regard to particular outlooks on life, to legitimize their choice as an accepted alternative in the public domain (Cerulo, 1997; Melucci, 1996), creating 'communities of meaning' (Cerulo, 1997, p. 394, see also Piore, 1995) and 'a collective commitment to some shared belief or principle' (Spar and La Mure, 2003 , p. 79). Individuals associated with such forms of civic engagement are seen as deriving value (Peteraf and Shanley, 1997) and recognition (Habermas, 1998b) from their actions, thereby reconstructing and reinforcing aspects of their identity (Rowley and Moldaveanu, 2003; Smith, 2001, 2002).

Significantly, the impact of globalization has led to the increasing migration of the target of civic engagement from political systems (e.g., nation states) to large (especially multinational) corporations, with powerful civil society associations and non-governmental organizations (NGOs) such as Greenpeace, Amnesty International, or WWF beginning to target globally discernable branded corporate entities. As the No Logo debate shows, the best known brands often face the highest pressure. As claimed by Habermas (2001), globalization has led to a shift in power from national political authorities to corporations, often resulting in acrimonious debates over their roles and responsibilities (Matten et al., 2003). Identity-driven civic engagement has increasingly confronted MNCs with ever rising expectations, be they in the area of human rights protection, poverty reduction, health or other societal issues (Margolis and Walsh, 2003; Matten and Crane, 2005). Beck (2000, p. 68) has termed this phenomenon 'globalization from below' while Dryzek (1999, p. 44) describes it as 'para-governmental activities' that manifest themselves as direct pressures on corporations.

It is important to recognize that while no hard estimate exists with regard to the material impact of anti-brand activism arising out of growing civic engagements, its importance is underscored by past experiences of consumer boycotts arising out of similar circumstances: in the late 90s, Nike's sales and shares suffered following a New York times report of a leaked internal audit that revealed serious human rights and environmental problems concerning the company's Vietnamese suppliers. The NGO Working assets Citizen Action seized on the story and generated about 33,000 letters to Nike's CEO demanding fair wages and working conditions. Subsequently, several students groups joined in, calling for a boycott of Nike products, which was further exacerbated by Michael Moore's provocative depiction of Nike's 'super brand' (Wootcliff and Deri, 2001). Financial estimates of corporate loss, although rare, are claimed by Kinght and Pretty (2000) to the extent of $\mathcal{K}^{10-15}$ million per day caused by consumer boycott of Shell following civic activism over the Brent Spar case. An estimated $\$ 2$ billion loss is attributed to civic campaigns and boycotts following Exxon Mobil's controversial stand on climate change. A poll conducted by Greenpeace shows that Esso's share of regular customers fell by $7 \%$ as a reaction to the company's adverse position on the Kyoto agreement (Aaker, 2004). In the current campaign against Coca Cola, the corporation is accused of human right violations 
in Colombia. About 20 leading universities in the USA and Canada have terminated their contracts with Coca Cola, banning the corporation's products from their campuses. Even though the monetary effects of such a boycott up to now might be negligible (at the Michigan university, for example, the company is projected to be loosing sales of about $\$ 1.4$ million per year), the reputational effects of the same are yet indeterminate (Kreye, 2006).

Indeed, consumer boycott is not a new phenomenon. Breen (1988) has described how consumer boycott of British manufactured goods was one of the defining moments of the American national awareness. Most significantly, a majority of the brand consuming population does not have to turn into anti-brand activists in order for a corporation to suffer from boycotts and negative publicity. In fact, as the example of Nike shows, civic activism, of the kind described above, very often has its roots in a small but vocal minority who are able to influence public opinion through their salient acts. Further, brand consumption may be adversely affected in large parts of a corporation's global marketplace, including those in developing countries that do not share similar identity forming dynamics as in postindustrial western societies, purely by the political weight that activists operating in the latter are able to wield on the whole industry. As the case of the Nestle infant formula debacle in Africa shows (Tapscott and Ticoll, 2003), consumer boycott and activism against Nestle in the U.S. was powerful enough to exert pressure on the company to alter its marketing techniques, despite a relatively low level of similar opposition among its African consumers. Big brands, thus, may be made to suffer on account of actions of a relative minority of its subscribers (even nonusers), who are moved to express their self-identity needs through an opposition of the brand's projected values/actions or those of its parent company.

Even though civic engagement and activism are not new in themselves, identifying corporations as their targets is a phenomenon of growing importance and growing impact (Crossley, 2002; Hertz, 2001). There is a rising awareness, both in management theory and in managerial practice, of the growing power of environmentalist groups, human rights activists and charity organizations to influence the bottom line (Klein et al., 2004; Rowley and Moldoveanu, 2003). As claimed by Thompson et al.
(2006, p. 60),"a relative small number of brand avoiders could be the impetus to a cultural tipping point." Individuals participating in acts of instant solidarity, linking their life stories to the narratives written by activist groups, often times discover that consumption decisions (or, more accurately, nonconsumption decisions) are an efficient means to communicate moral and political statements. They shop for a better world. As described by Will et al. (1989, p. 143), 'Every time you step up to a cash register, you vote. When you switch from one brand to another, companies hear you clearly.'

The growing role of identity redefinition through consumption on the one hand and seeking congruence of one's life values with those enacted by corporations on the other, creates the basis of conflict between brand support and brand opposition. The latter is generated by a public perception that the corporation behind the brand is violating ethical standards in general or the legitimate expectations of its stakeholders in particular. Since brand support has been linked to the credible corporate promise of enriching the lives of consumers and other stakeholders, its perceived violation stands to reveal the falsehood of that promise. Thus, it is within the framework of CSR that the two societal phenomena, corporate branding and anti-brand activism, merge.

\section{CSR: balancing consumption values with life values}

While both identity-driven consumption and identity-driven activism have risen from societal transformation, the simultaneous consideration of the two in the context of any particular corporation renders salient the entire range of its activities. While on the one hand successful value-based corporate branding encourages consumers to see themselves in light of the brand narrative (Belk et al., 1989; Bhattacharya and Sen, 2003), on the other it could raise the bar for high ethical standard in its core business activities (Kay, 2006). Value-focused branding runs the risk of severe reputation and financial backlashes when corporate behavior contradicts the branded values and when corporate misconduct becomes front-page news. The more successful the brand is, the heavier the disappoint- 
ment of loyal customers and the more serious the reputation damage, as the overarching brand becomes the point of reference for external critics. As argued by Bhattacharya and Sen (2003), while a perceived consumer-corporation value fit increases customers' identification with the corporation, a visible violation of the self-imposed normative standards will have the contrary effect: the more successfully a brand has been value-laden and positioned as a reliable partner, the greater the disappointment in case of corporate misconduct.

As a consequence, brand success becomes deeply entwined within a corporation's CSR performance (Zyglidopoulos, 2002). The anti-sweatshop movement, for example, has established an understanding of moral responsibility that ignores the legal borders of a corporation and involves an argument that agents are responsible for injustice by virtue of their structural connection to it, even though they are not to blame for it' (Young, 2003, p. 40). If fairness is a core value of a corporate brand, it is demanded not only at the customer interface but throughout the whole supply chain behind the brand (Roberts, 2003). Thus, even suppliers' behavior turn into an element of the brand narration, a reason why Nike has been held accountable for child labor, unfair working conditions and unfair wages in the production plants of its (legally independent) suppliers from developing countries. The view that business integrity cannot be outsourced has led to "business integrity becoming part of a brand' (Tapscott and Ticoll, 2003, p. 152; Aaker, 2004), demanding that brands possess 'ethical robustness' (Steeger, 2003, p. 175) - a growing requirement that a successful brand be supported by an ethical corporation.

Clearly, then, fundamental consideration of CSR is necessary to develop a consistency and balance between a brand's 'identity-giving' role in the domain of consumption, and a branded corporation's affirmation of consumers' broader life goals. While manifold definitions of CSR are available, ranging from narrow, mainly legal interpretations of a firm's social responsibility (Friedman, 1970) to broader interpretations that include economic, legal, moral, and philanthropic responsibilities (Caroll, 1979); passive (i.e., 'do no harm'; Drucker, 1973) to active concepts of corporate involvement in solving key societal challenges (i.e., 'do good'; Matten and Crane, 2005), it is vital for a corporation to assess the relevant qualities of CSR engagement that will be desired and relied upon by its target audience (including all stakeholders) in making identity defining judgments. Significantly, the challenge of brand management is likely to require, (A). Scoping of the relevant CSR domain, and (B). ensuring a balance between perceived consumption values and life values. Within the design and implementation such a balance then, lies the secret of successful brand management that is able to resolve the conflict between brand success and anti-brand activism. A thorough analysis of the congruence or dissonance between consumption values and life values might help to understand why some corporate brands are more successful than others in creating affective bonds while others attract brand resistance, avoidance and provoke negative representations in popular culture. In the following section we propose four scenarios arising out of possible combinations of life and consumption values.

\section{Strategic guidelines: balance/imbalance scenarios}

Essentially, four scenarios may be envisaged: I. Stakeholders perceive both the consumption values offered by a brand and the life values, offered by its parent corporation through the entire range of its activities, favorable and consistent with each other (i.e., both consumption and self-identities congruent); II. Stakeholders perceive the consumption values to be favorable but life values unfavorable; III. Stakeholders perceive consumption values to be unfavorable but life values favorable; and IV. Stakeholders perceive both consumption and life values to be unfavorable (Figure 2).

Scenario I, of course, is the most cherished position to be from a corporation's perspective. Not only are the consumption values embodied by the brand seen as preferable to other competing brand values, but the corporation as a whole connotes life values that the consumers find self-identity affirming. Thus, both consumption and self-identity expression needs are satisfied by the brand. Pearce II and Doh (2005), for example, have described such a congruence scenario with the IBM brand standing for 'innovative solutions' and the company projecting 'reinventing learning' as a comprehensive life value 


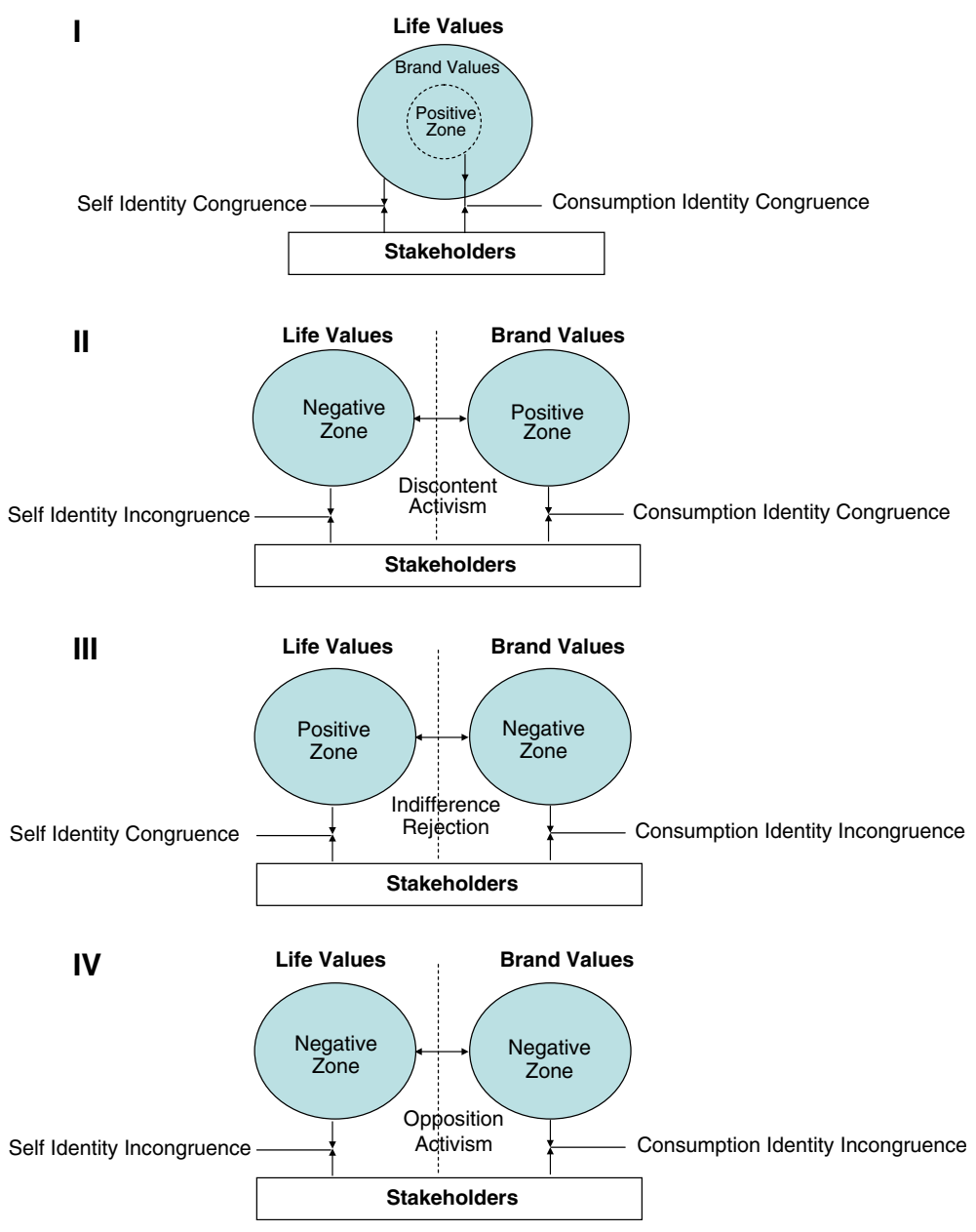

Figure 2. Consumption and life value scenarios.

throughout its marketplace, philanthropic, and operational activities.

Scenario II implies that while consumers of a brand find the consumption values to be congruent with their desired identity, the corporation projects negative life values leading to problems in reconciling the two. As described earlier, this may have been the scenario with regard to opposition to Nike's alleged supply chain involvement. It is significant to note that while one group of stakeholders (say consumers) may be content with the aspect of consumption identity congruence ignoring other life values as they might potentially pertain to the company's multifarious activities, another group of stakeholders (say governments/NGOs/journalists) may react negatively to the perceived incongruence with desired life values. That is to say that brand support and anti-brand activism may coexist in this scenario, although driven by different stakeholders. The strategic challenge facing management with regard to the possible discontent or activism is to turn serious attention to reevaluation of the relevant activities, potentially in partnership with the critics with a view toward developing and communicating authentic solutions. Werre (2003) has provided an example of a firm's effort to address perceived inadequacies in life values and seek moral legitimacy by describing Chiquita's decision to engage in extensive discourse with the very NGOs that were its strongest critics with regard to firm management practices in order to develop industry-wide standards of social responsibility. It is important also to point out that severe reputation risk awaits those who merely simulate corporate integrity (Spar and La Mure, 2003), with 'window-dressing' of brands to avoid CSR scrutiny likely to be confronted with 
boycotts and symbolic actions such as adbusting ("culture jamming"), hacking corporate websites, instituting buy-nothing days, i.e., actions that aim at tearing down facades (Lasn, 1999; Rumbo, 2002).

Scenario III implies that while most stakeholders perceive a corporation as embodying favorable life values, the consumption values projected by its brand are found to be inadequate or negative, leading to indifference or even rejection of the brand in favor of its competitors. The Co-op food retail chain in the U.K., has, for example, suffered in terms of competitive positioning and market share of its brand in relation to competition given unfavorable perception regarding the values offered by its stores although its record in terms of life values (e.g., community involvement, fairness to employees, partnership) are considered peerless and exemplary. The management challenge here, of course, is to leverage life-value advantages to create consumption value enhancement and differentiation. Guidelines include: A. segmenting consumers in terms of their receptivity to life-value messages, followed by effective communication of the same (in the previous example, the firm in question never communicated to its target audiences its superiority over other food retailers in terms of its CSR performance as judged by third parties); and B. reevaluation of target consumers' consumption goals, and aligning delivery systems to meet such goals.

Finally, scenario IV implies that stakeholders perceive both consumption and life values to be negative, leading to opposition and activism directed toward the corporation and its brand. Although such scenarios are infrequent, early forays by western pharmaceutical companies in the developing world in the area of reproductive therapies had experiences similar incongruence (Basu and Chattopadhyay, 1995). The recommended course of action here, would involve a quick reassessment by the firm of its strategic rationale followed by appropriate corrective actions, or in the extreme, withdrawal from the marketplace.

\section{Conclusions}

While anti-brand activism has not yet reached proportions that would upset the brand applecart, it warrants close attention on the part of corporations that have significantly invested in terms of their branding. In addition, although anti-brand activism has been limited so far in terms of its appeal among a section of citizenry in post-industrial western societies, its ability to damage a global brand is significant. Such might occur through the encouragement of legislative actions in these societies, by revenue-damaging boycotts, and as a result of influencing consumer perceptions in parts of the world where identity-imparting aspects of brands may be less relevant than in post-industrial societies. It is thus significant to recognize that both brand support and brand opposition rise from similar societal phenomena, and that the resolution of conflict can be best brought about by ensuring that both consumption values and life values evoked by corporations are viewed favorably by stakeholders as lending coherence in their search for identity.

Actively exploring the described links between identity, consumption, and values is likely to enrich our perception of brands and influence both branding theory and practice. Specifically

1. While branding literature has indicated a shift from benefit-driven product branding to value-driven corporate branding, it has largely neglected the potential backlashes resulting from such a strategic shift (see critically, Thompson et al., 2006). Future research might benefit from our proposed view that (corporate) brand success and its opposition are intimately linked.

2. The link between value-driven consumer decision-making and branding approaches need empirical research to understand if indeed corporate branding works better in some industries than in others, or within particular national cultures as opposed to others.

3. The "cultural vulnerability" (Thompson et al., 2006, p. 61) of corporate branding strategies calls for a closer examination of counter-cultural activities and actors in order to understand how and under which conditions anti-brand narrations leave their counter-cultural niche and permeate the mainstream perception of a brand. Since a significant part of counter-cultural expressions emerge on the web (newsgroups, blogs, 
chat, rooms, etc.), ethnographic methods that are adopted to study online-communities (Kozinets, 2002) might help to broaden the understanding of anti-brand effects.

4. Unifying the two streams of research - CSR and branding - is likely to shed insights into how a company might achieve fulfillment of promises to its entire set of stakeholders through a holistic portfolio of activities.

\section{References}

Aaker, D. J.: 1996, Building Strong Brands (Free Press, New York).

Aaker, D. J.: 2004, 'Leveraging the Corporate Brand', California Management Review 46(3), 6-18.

Aaker, D. J. and E. Joachimsthaler: 2000, Brand Leadership (Simon \& Schuster, London).

Appadurai, A.: 1990, 'Disjuncture and Difference in the Global Cultural Economy', Theory, Culture \& Society 7, 295-310.

Arnould, E. J. and L. L. Price: 2000, 'Authenticating Acts and Authoritative Performance Questing for Self and Community', in S. Ratneshwar, D. G. Mick and C. Huffman (eds.), The Why of Consumption Contemporary Perspectives on Consumer Motives, Goals, and Desires (Routledge, London), pp. 140-163.

Basu, K. and A. Chattopadhyay: 1995, 'Marketing Pharmaceuticals to Developing Nations: Research Issues and a Framework for Public Policy', Canadian Journal of Administrative Sciences 12(4), 300-313.

Beardsworth, A. and A. Bryman: 1999, 'Late Modernity and the Dynamics of Quasification: The Case of the Themed Restaurant', Sociological Review 47, 228-257.

Beck, U.: 2000, What is Globalization (Blackwell Publishers, Oxford).

Beck, U., W. Bonss and C. Lau: 2003, 'The Theory of Reflexive Modernization. Problematic, Hypotheses and Research Programme', Theory, Culture \& Society 20, 1-33.

Beck, U., A. Giddens and S. Lash: 1995, Reflexive Modernization (Stanford University Press, Stanford).

Beck-Gernsheim, E. and U. Beck: 2002, Individualization: Institutionalized Individualism and its Social and Political Consequences (Sage, London).

Belk, R. W.: 1988, 'Possession and the Extended Self, Journal of Consumer Research 15, 139-168.

Belk, R. W., M. Wallendorf and J. F. Sherry, Jr.: 1989, 'The Sacred and the Profane in Consumer Behavior: Theodicy on the Odyssey', Journal of Consumer Research 16, 1-38.
Berry, L. L.: 2000, 'Cultivating Service Brand Equity', Journal of the Academy of Marketing Science 28, 128-137.

Bethune, B.: 2000, 'Waging a War on Branding', Maclean's 113, 01/31-52.

Bhattacharya, C. B. and S. Sen: 2003, 'ConsumerCompany Identification: A Framework for Understanding Consumers' Relationships with Companies', Journal of Marketing 67, 76-88.

Breen, T. H.: 1988, 'Baubles of Britain: The American and Consumer Revolution of the Eighteenth Century', Past and Present 119, 73-104.

Business Week 2005 (August 1), 'The 100 Top Brands'.

Carroll, A. B.: 1979, 'A three-dimensional conceptual model of corporate performance', Academy of Management Review 4(4), 497-505.

Castells, M.: 1996, The Rise of the Network Society (Blackwell Publishers, Oxford).

Cerulo, K. A.: 1997, 'Identity Construction: New Issues, New Directions', Annual Review of Sociology 23, 385409.

Chevalier, M. and G. Mazzalovo: 2004, Pro Logo: Brands as a Factor of Progress (Palgrave Macmillan, New York).

Clark, K. B. and T. Fujimoto: 1990, 'The Power of Product Integrity', Harvard Business Review 68, 107-118.

Cleary, D. P.: 1981, Great American Brands (Fairchild, New York).

Corrigan, P.: 1997, The Sociology of Consumption (Sage, London).

Cova, B.: 1997, 'Community and Consumption Towards a Definition of the 'Linking Value' of Product and Services', European Journal of Marketing 31, 297-316.

Cramp, B.: 2001, 'What's Next for No Logo Naomi?', Ad Age Global 2(October), 10.

Crossley, N.: 2002, 'Global Anti-Corporate Struggle: A Preliminary Analysis', British Journal of Sociology 53(4), 667-691.

Czellar, S. and G. Palazzo: 2004, 'The Impact of Perceived Corporate Brand Values on Brand Preference: An Exploratory Empirical Study', 33rd European Marketing Academy Proceedings (European Marketing Academy, Murcia).

de Chernatony, L. : 1999, 'Brand Management through Narrowing the Gap Between Brand Identity and Brand Reputation', Journal of Marketing 61, 157-179.

de Chernatony, L. and M. H. B. McDonald: 1992, Creating Powerful Brands (Butterworth-Heinemann).

Douglas, M.: 1975, Implicit Meaning: Essays in Anthropology (Routledge, London).

Drucker, P.: 1973, Management Tasks, Responsibilities, Practices (Harper \& Row, New York).

Dryzek, J. S.: 1999, 'Transnational Democracy', Journal of Political Philosophy 7(1), 30-51. 
Durgee, J. F., G. Colarelli O'Connor and R. Veryzer: 1996, 'Observations: Translating Values into Product Wants', Journal of Advertising Research 36(6), 90-99.

Economist: 2001, 'Who's Wearing the Trousers?' 360(09/08), 27-29.

Elliot, R.: 1997, 'Existential Consumption and Irrational Desire', European Journal of Marketing 31, 285-296.

Elliot, R. and K. Wattanasuwan: 1998, 'Brands as Symbolic Resources for the Construction of Identity', International Journal of Advertising 17, 131-144.

Erikson, E. H.: 1968, Identity: Youth and Crisis (Faber and Faber, London).

Festinger, L.: 1957, A Theory of Cognitive Dissonance (Stanford University Press, Stanford).

Firat, A. F. and N. Dholakia: 1998, Consuming People From Political Economy to Theaters of Consumption (Routledge, London).

Fournier, S.: 1998, 'Consumers and Their Brands: Developing Relationship Theory in Consumer Research', Journal of Consumer Research 24, 343-373.

Friedman, M.: 1970, 'The social responsibility of business is to increase its profit', The New York Times Magazine, 13 September, reprinted in T. I. White (ed.), 1993. Business Ethics A Philosophical Reader (Prentice Hall, Englewood Cliffs, NJ), pp. 162-167.

Fromm, E.: 1976, To Have or To Be (Harper and Row, New York).

Gabriel, Y. and T. Lang: 1995, The Unmanageable Consumer Contemporary Consumption and its Fragmentation (Sage, London).

Gecas, V.: 2000, 'Value Identities, Self-Motives, and Social Movements', in S. Stryker, T. J. Owens and R. W. White (eds.), Self, Identity, and Social Movements (University of Minnesota Press, Minneapolis), pp. 93-109.

Giddens, A.: 1991, Modernity and Self-Identity (Polity Press, Cambridge).

Habermas, J.: 1987, The Theory of Communicative Action 2(Beacon Press, Boston).

Habermas, J.: 1996, Between Facts and Norms (MIT Press, Cambridge).

Habermas, J.: 1998, 'Jenseits des Nationalstaates? Bemerkungen zur Folgeproblematik der wirtschaftlichen Globalisierung,, in U. Beck (eds.), Politik der Globalisierung (Suhrkamp, Frankfurt), pp. 67-84.

Habermas, J.: 1998, The Inclusion of the Other: Studies in Political Theory (MIT Press, Boston).

Habermas, J.: 2001, The Postnational Constellation: Political Essays (MIT Press, Boston).

Hatch, M. J. and M. Schultz: 2001, 'Are the Strategic Stars Aligned for Your Corporate Brand?', Harvard Business Review 79, 128-134.
Hatch, M. J. and M. Schultz: 2003, 'Bringing the Corporation into Corporate Branding', European Journal of Marketing 37, 1041-1064.

Hertz, N.: 2001, 'Better to Shop than to Vote?', Business Ethics: A European Review 10, 190-193.

Hitlin, S.: 2003, 'Values as the Core of Personal Identity: Drawing Links Between Two Theories of Self, Social Psychology Quarterly 66, 118-137.

Hitlin, S. and J. A. Piliavin: 2004, 'Values: Reviving a Dormant Concept', Annual Review of Sociology 30, 359-393.

Hjelt, P.: 2004, 'The World's Most Admired Companies', Fortune March 8, 30-37.

Holt, D. B.: 1997, 'Poststructuralist Lifestyle Analysis: Conceptualizing the Social Patterning of Consumption in Postmodernity', Journal of Consumer Research 23, 326-350.

Kamakura, W. A. and T. P. Novak: 1992, 'Value-system Segmentation: Exploring the Meaning of LOV', Journal of Consumer Research 19, 119-132.

Kay, M. J.: 2006, 'Strong Brands and Corporate Brands', European Journal of Marketing 40(7/8), 742-760.

Keller, K. L.: 2003, 'Brand Synthesis: The Multidimensionality of Brand Knowledge', Journal of Consumer Research 29, 595-600.

Klein, J. G., N. C. Smith and A. John: 2004, 'Why We Boycott: Consumer Motivations for Boycott Participation', Journal of Marketing 68, 92-109.

Klein, N.: 2000, No Logo (Picador, New York).

Kozinets, R. V.: 2002, 'The Field Behind the Screen: Using Netnography for Marketing Research in Online Communities', Journal of Marketing Research 29, 61-72.

Knight R. F. and D. I. Pretty (2000) Brand risk management in a value context, Templeton Briefing (Oxford University), pp. 24-25.

Kreye, A. (2006) Zynische Realitaeten, Sueddeutsche Zeitung, January 11.

Lafferty, B. A. and R. E. Goldsmith: 1998, 'Corporate Credibility's Role in Consumers' Attitudes and Purchase Intentions when a High Versus a Low Credibility Endorser is Used in the Ad', Journal of Business Research 44, 109-116.

Lasn, K.: 1999, Culture Jam. How to Reverse America's Suicidal Consumer Binge - and Why We Must (HarperCollins Publishers, New York).

Marcuse, H.: 1964, One-Dimensional Man (Beacon Press, Boston).

Margolis, J. D. and J. P. Walsh: 2003, 'Misery Loves Companies: Rethinking Social Initiatives by Business', Administrative Science Quarterly 48, 268-305. 
Matten, D. and A. Crane: 2005, 'Corporate citizenship: Towards an extended theoretical conceptualization', Academy of Management Review 30(1), 166-179.

Matten, D., A. Crane and W. Chapple: 2003, 'Behind the Mask: Revealing the True Face of Corporate Citizenship', Journal of Business Ethics 45, 109120 .

McCracken, G.: 1986, 'Culture and Consumption: A Theoretical Account of the Structure and Movement of the Cultural Meaning of Goods', Journal of Consumer Research 13, 71-84.

Melucci, A.: 1996, Challenging Codes: Collective Action in the Information Age (Cambridge University Press, New York).

O'Donohoe, S.: 1999, 'Consumption, Identity and Coping Strategies in Times of Crisis', Advances in Consumer Research 26, 421-423.

O'Malley, D.: 1991, 'Brand Means Business', Accountancy 107, 107-108.

Palazzo, G. and U. Richter: 2005, 'CSR Business as Usual? The Case of the Tobacco Industry', Journal of Business Ethics 61, 387-401.

Pearce, J. A. II. and J. P. Doh: 2005, 'The High Impact of Collaborative Social Initiatives', MIT Sloan Management Review, Spring, 30-38.

Peteraf, M. and M. Shanley: 1997, 'Getting to Know You: A Theory of Strategic Group Identity', Strategic Management Journal 18, 165-186.

Pine, B. J., II and J. H. Gilmore: 1999, The Experience Economy (Harvard Business School Press, Boston).

Piore, M. J.: 1995, Beyond Individualism (Harvard University Press, Cambridge, MA).

Reed, A., II: 2004, 'Activating the Self-Importance of Consumer Selves: Exploring Identity Salience Effects on Judgements', Journal of Consumer Research 31, 286295.

Ritzer, G.: 1999, Enchanting a Disenchanted World: Revolutionizing the Means of Consumption (Pine Forge Press, Thousand Oaks).

Roberts, S.: 2003, 'Supply Chain Specific? Understanding the Patchy Success of Ethical Sourcing Initiatives', Journal of Business Ethics 44, 159-170.

Rowley, T. J. and M. Moldoveanu: 2003, 'When Will Stakeholder Groups Act? An Interest- and Identitybased Model of Stakeholder Group Mobilization', Academy of Management Review 28, 204-219.

Rumbo, J. D.: 2002, 'Consumer Resistance in a World of Advertising Clutter: The Case of Adbusters', Psychology E Marketing 19, 127-148.

Schau, H. J.: 2000, 'Consumer Imagination, Identity and Self-expression', Advances in Consumer Research 27, $50-56$.
Schmitt, B. and A. Simonson: 1997, Marketing Aesthetics. The Strategic Management of Brands, Identity, and Image (Free Press, New York).

Schor, J.: 1991, The Overworked American: The Unexpected Decline of Leisure (Basic Books, New York).

Schouten, J. W.: 1991, 'Selves in Transition: Symbolic Consumption in Personal Rites of Passage and Identity Reconstruction', Journal of Consumer Research 17, 412425.

Schultz, M. and L. de Chernatony : 2002, 'The Challenge of Corporate Branding', Corporate Reputation Review 5, 105-112.

Sennett, R.: 1998, The Corrosion of Character: The Personal Consequences of Work in the New Capitalism (W. W. Norton \& Company, New York).

Shamir, B., R. J. House and M. B. Arthur: 1993, 'The Motivational Effects of Charismatic Leadership: A Self-concept Based Theory', Organizational Science 4, 577-594.

Shankar, A. and J. A. Fitchett: 2000, 'Having, Being and Consumption', Journal of Marketing Management 18, 501-516.

Siegel, S. M.: 2000, 'Don't Lump Brands With Sweatshops', Brandweek 41, 06/12-34.

Simoes, C. and S. Dibb: 2001, 'Rethinking the Brand Concept: New Brand Orientation', Corporate Communications 6, 217-224.

Smith, J.: 2001, 'The Battle of Seattle and the Future of Social Movements', Mobilization 6, 1-19.

Smith, J.: 2002, 'Bridging Global Divides? Strategic Framing and Solidarity in Transnational Social Movement Organizations', International Sociology 17, 505-528.

Spar, D. L. and L. T. La Mure: 2003, 'The Power of Activism: Assessing the Impact of NGOs on Global Business', California Management Review 45, 78-101.

Steeger, U.: 2003, Corporate Diplomacy (Chichester, Wiley).

Tapscott, D. and D. Ticoll: 2003, The Naked Corporation (Free Press, New York).

Taylor, C.: 1989, Sources of the Self: The Making of the Modern Identity (Cambridge University Press, Cambridge, MA).

Thompson, C. J., A. Rindfleisch and Z. Arsel: 2006, 'Emotional Branding and the Strategic Value of the Doppelgänger Brand Image', Journal of Marketing 70, 50-64.

Tilley, C.: 1999, 'Build-In Branding: How to Engineer a Leadership Brand', Journal of Marketing Management 15, 117-133.

Touraine, A.: 1994, Qu'est-ce que la Démocratie? (Fayard, Paris). 
Urde, M.: 1999, 'Brand Orientation: A Mindset for Building Brands into Strategic Resources', Journal of Marketing Management 15, 117-133.

Urde, M.: 2003, 'Core Value-based Corporate Brand Building', European Journal of Marketing 37, 1017-1040.

Useem, J.: 2004, Should We Admire Wal-Mart? Fortune (03/08), 44-46.

Werre, M.: 2003, 'Implementing corporate responsibility - The Chiquita case', Journal of Business Ethics 44, 247-260.

Will, R., et al.: 1989, Shopping for a Better World (Council for Economic Priorities, New York).

Wootcliff, J. and C. Deri: 2001, 'NGOs: The New Super Brands', Corporate Reputation Review 4(2), 157-164.

Young, I. M.: 2003, 'From Guilt to Solidarity Sweatshops and Political Responsibility', Dissent 50(2), 39-44.

Zyglidopoulos, S. C.: 2002, 'The Social and Environmental Responsibilities of Multinationals: Evidence from the Brent Spar Case', Journal of Business Ethics 36, 141-151.

Guido Palazzo
HEC,

University of Lausanne,

Internef, Lausanne, VD, 1003, Switzerland

E-mail: Guido.Palazzo@unil.ch

Kunal Basu

Said Business School, University of Oxford, EGrove Park, Oxford, OX1 5NY, UK

E-mail:kunal.basu@sbs.ox.ac.uk 